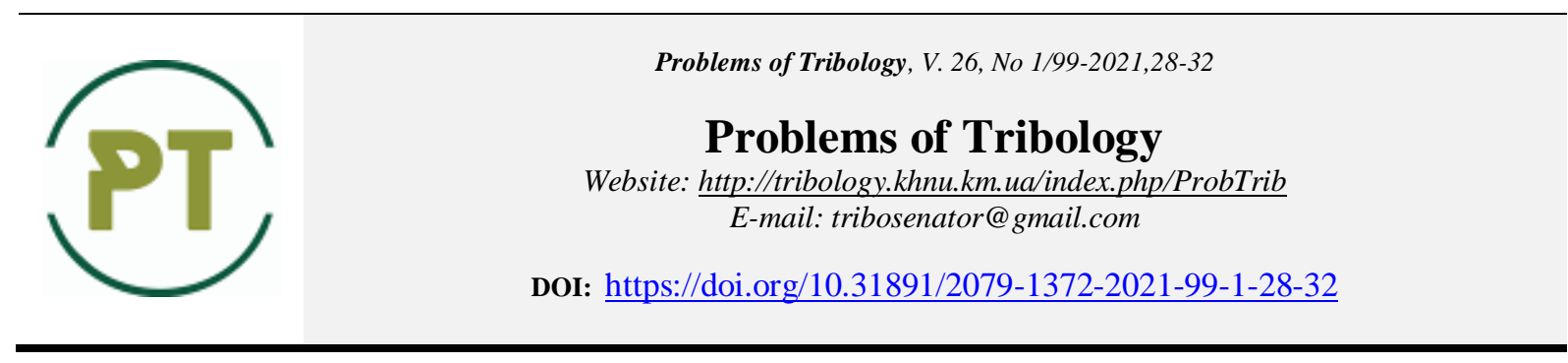

\title{
Closed ventilation and filtering system for cleaning of welding aerosols at deposition
}

\author{
V. Chigarev ${ }^{1}$, Yu. Logvinov ${ }^{2 *}$ \\ ${ }^{l}$ Mariupol State higher educational institution 'Priazovsky state technical university, Mariupol, Ukraine \\ ${ }^{2 *}$ Mariupol institute Interregional Academy of Personnel Management city of Mariupol. Ukraine \\ E-mail: $\underline{07 \log 07 @ \text { gmail.com }}$
}

\begin{abstract}
In the article the questions of development of construction of the closed ventilation and filtering system (CVFS) are considered on cleaning of air-gas mixture at deposition. The offered system consists of gas in-take, filters, containers for assembling of hard parts, hard constituent of welding aerosol (TSSA), by the gaseous constituent of welding aerosol (GSSA) and corps, special vent system with adjusting of speed and volume of extraction. Conducted research for cleaning of welding aerosols (SA) at deposition of high wear proof alloys of type of sormite with the use of the CVFS. Special CVFS is used, filters in particular mechanical, electric, chemical (sorption). Extraction of air-gas mixture from the area of melting of electrode and welding bath of is carried out by the pipe of small diameter, with adjusting of speed and volume of extraction passes the system of filtration the special vent system where clears up from TSSA. Thus cleared gas mixture is used as gas defense at depositing.

It is necessary it is not simple to catch SA, but to filter in the closed system, clean and give filtered clean $\mathrm{y}$ air in the area of deposition, technology and metallurgical properties of process of depositing must not be broken here. Features of the mechanical cleaning are in technologies of deposition, characterized that air-gas mixture has a temperature which influences on a sorbent. The mechanical cleaning by the centrifugal chamber of cleaning $(\mathrm{CCC})$ is the modernized cyclone filter where centrifugal forces and gravities were used. Differs from existent cyclic filters a presence by a conical spiral insertion and rearranged surface of cone which engulfs it. In the entrance tangential union coupling appears, divided aero mixture into a few streams of entered in a spiral insertion. In the electric filter (electrostatic) electric forces operate on particles and gas molecules (based on the phenomena ionization of gas molecules, by an electric charge in the electric field). An electric charge is revealed to the particles, and they under the action of the electric field are besieged from a gas stream. If such gas, containing the several of transmitters of charges, to place between electrodes, connected with the source of high voltage, ions and electrons will begin to move to on power the field lines. This is important during neutralization of GSSA.
\end{abstract}

Keywords: harmful matters, welding aerosols, closed ventilation and filtering system, gaseous constituent of welding aerosol, mechanical filter, electric filter.

\section{Introduction}

Receipt of deposited metal with necessary wearproofness provided application, as a rule, depositing material of containing the alloying elements of the required amount. At depositing of high-alloyed of wear proof alloys the far of TSSA is selected, GSSA, polluting environment [1-4].

For the decline of selection of harmful constituents in air-gas medium during the lead through of deposition works need development of additional devices for their catching. By the area of tribology researches are the processes, of frictions, wears [1].

In it turn of process this to work-hardening of iron and steel machines, it is the real decision of task of wear of machines and mechanisms. 
The filtration and ventilation systems are in-process [2-3] presented which partly decides cleaning of GSSA and TSSA at welding and depositing of wear proof alloys. Offered CVFS allows to clean SA here saving chemical composition for forming of deposition guy-sutures without extract in an atmosphere.

At welding or deposition in-process of a vent system the optimum mode of speed of sucking of volumes of the deleted air-gas mixture is set for providing of necessary chemical composition of deposited metal or welding guy-sutures.

Different foreign analogues are in-process [4] considered on filters and vent systems applied in a welding and surfacing production with extract in the atmosphere of TSSA and GSSA, that worsens the sanitary-hygienic indexes of environment

\section{The objective of the article}

Development of construction of CVFS, to find optimum technical decisions and decrease TSSA and GSSA, improve the working conditions at deposition of taking into account international standards.

\section{Main materials}

Development of construction of CVFS with the use of the special filters allows to neutralize harmful matters, and air-gas mixture. Air-gas mixture is taken away from the area of melting of electrode material and welding bath the special gas sampler passes filtration through the system of the special filters TSSA and GSSA delete in which. In same a gas sampler consists of pipes of different diameter, which are disposed in a demi hull and set in the area of melting of electrode metal.

Extraction of air-gas mixture from the area of melting of the electrode and welding bath is carried out by the pipe of small diameter of fig. 1.b (1) the special vent system with adjusting of speed and volume of hood and passes the system of filtration, where clears up from TSSA presented on fig. 1.

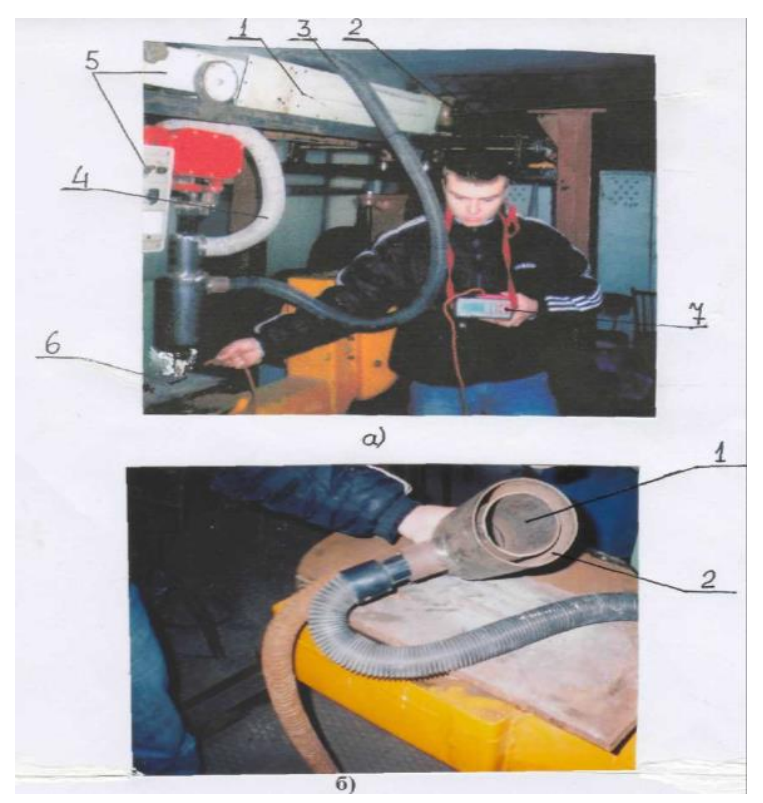

Fig. 1. Presented in CVFS at localization and SA neutralizes at deposition: a) there is an of principle chart of delete of harmful matters and SA on-condition: 1 - filter three-stage; 2 - pump; 3 -supply of air after filtration; 4 - -suction of harmful matters and SA; 5 - deposition automat; 6 - deposition deposited metal; 7 -measuring from the help of gas analyzer. b) specially developed adaptation for suction of harmful matters and SA, and serve of the filtered air in a working area: 1 - -chamber for suction of SA (on walls particles of dust and soot are visible); 2 - chamber of supply of the cleared air after filtration.

Where upon, the cleared gas mixture is used as gas protection at deposition [5]. It is necessary not simply to catch SA and to filter in the closed system, clean and give the filtered clean air in the area of deposition, here must not be broken technologically and metallurgical processes of deposition. Offered CVFS simple and reliable in exploitation. The closed ventilation and filtration system consists of $3^{\mathrm{kh}}$ filters: mechanical; electric; chemical (sorption).

Features of the mechanical cleaning are in technologies of deposition, that air-gas mixture is characterized the temperature of $\mathrm{T}=800 \ldots 900^{\circ} \mathrm{c}$ away from the area of melting of electrode material. It is necessary to chill due to corrugated aluminum hose which reduce a temperature. A temperature influences on to the robot of sorbent. Mechanical cleaning by the centrifugal chamber of cleaning (CCC). 
The modernized cyclone filter (centrifugal forces and gravities were used) [6] of which differs from existing a presence by a conical spiral insertion and rearranged surface of cone which engulfs it. In exit tangential union coupling appears, divided aero mixture into a few for-currents of entering in a spiral insertion. There is more intensive transformation of energy of pressure to kinetic. Thus force of static pressure is already comparable with weight of particles and excels it. On fig.2. the mechanical cleaning is presented by CCC.

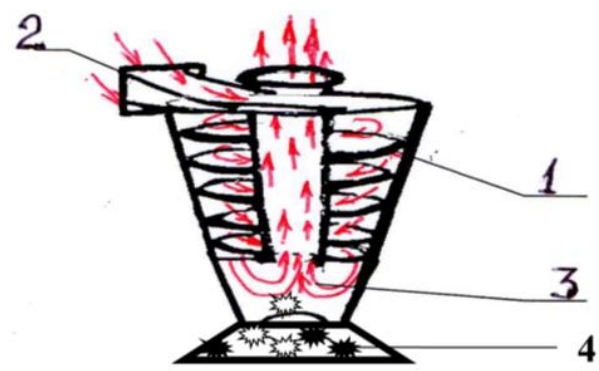

Fig. 2. Mechanical cleaning CVFS by CCC: 1 - spiral insertion; 2 - cleaning of SA; 3 - exit from the insertion of $\mathrm{SA} ; 4$ - container with particulate dispersible compounds

A determinative is independent motion of certain amount of spiral streams and cleared stream to the exhaust. In the process of such motion the increase of circuitous speed of aero mixture can attain on an output 70 $\mathrm{m} / \mathrm{s}$, that results in the large concentration of sputtering particles. In the entrance tangential union coupling appears, divided aero mixture into a few streams of entered in a spiral insertion. On an exit from an insertion here speed of current of air is made by $50 \ldots 70 \mathrm{~m} / \mathrm{ss}$.

Electric filters their principle of action explained action of electro--static forces. Electric forces operate on particles and gas molecules, based on the phenomena of ionization of gas molecules the electric field. An electric charge is revealed to the particles and they under the action of the electric field are precipitated from a gas stream.

If such gas, containing several of transmitters of charges, to place between electrodes, connected with the source of high tension, ions and electrons will begin to move to on power the field lines. That provides at neutralization of GSSA. TSSA in electrostatic precipitators clear up:

- sputtering d particles move to the electrodes with an opposite sign;

- precipitated on these electrodes; a dust, settling on electrodes by the shaken device, precipitated.

Practically charging of particles is performed at the key-in of particles through the crown of directcurrent between the electrodes of electrostatic precipitator. The general view of electrostatic precipitator is resulted on fig.3.

On crowning electrodes the direct current of high tension is given $30 \ldots 60 \mathrm{kV}$. Crowning an electrode has subzero polarity usually, an precipitating electrode is earthed. It is explained that a crown at such polarity is more steady, mobility of subzero ions is higher, than positive. The last circumstance is related to the acceleration of charging of sputtering. On a fig.3. the structural chart of electric filter is offered in CVFS.

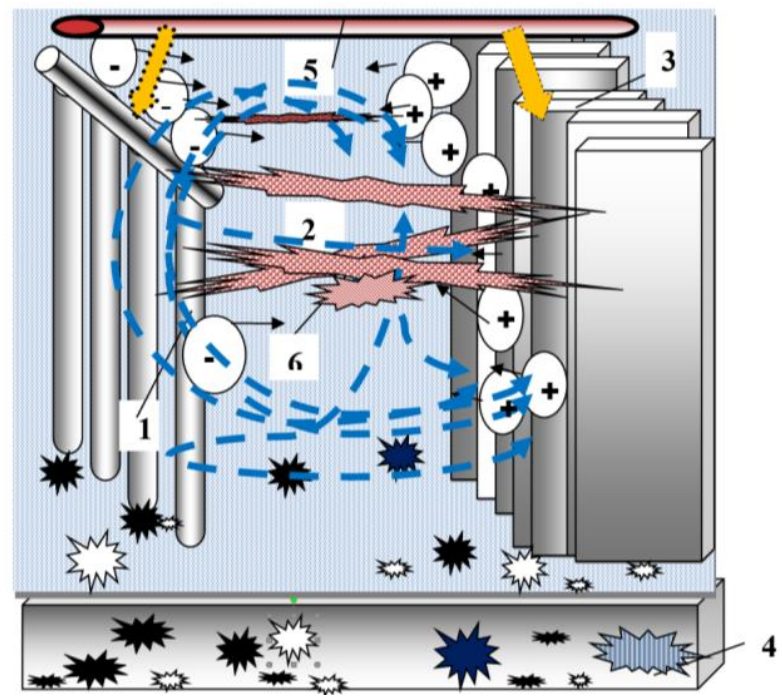

Fig. 3. Structural chart of electric filter in CVFS: 1 - thin wire rods; 2 - is created the electric field between electrodes, connected with the source of high tension; 3 - plates drank for besieging; 4 -container for collection was drunk including; 5 - shaking device; 6 - corona electrode. 


\section{Conclusions}

1. The construction of CVFS is offered for the decline of selection of harmful constituents, formed in an air-gas environment at deposition of wear proof alloys.

2. The improvement of alloying in deposited metal will allow to improve the process of work-hardening of machines, it is the real solution of task of wear and is the area of tribology researches.

\section{References}

1. http://tribology.khnu.km.ua/index.php/ProbTrib

2. Safronov I.I. Fundamentals of rational alloying of alloys. / I.I. Safronov - Chisinau: Shtiintsa, 1991 .$278 \mathrm{p}$.

3. Livshits L.S. Fundamentals of alloying of deposited metal / L.S., Livshits, N.A. Greenberg, E.G. Curcumelli. - M .: Mechanical engineering, 1969 . - 188 p.

4. Chigarev V.V. Sanitary-hygienic assessment of surfacing flux-cored tapes / V.V. Chigarev, O. G. Levchenko // Welding production. - 2004 - No. 12. - S. 35-37.

5. Logvinov Yu.V. Closed filtering system for neutralization and localization of welding aerosol during surfacing / Yu.V. Logvinov // Science and technology: mizhvuz. Topics. Zb. Sciences. Pr. - Mariupol: DVNZ 'PDTU'. - 2018.- VIP. 19. - P.32-35.

6. Breca D. Zeolite molecular sieve / D. Breca. - M: Mir, 1980.- T.1-504s. 
Чігарьов В.В., Логвінов Ю.В. Замкнута фільтровентіляційна система для очищення зварювальних аерозолів при наплавленні

У статті розглянуті питання розробки конструкції замкнутої фільтровентиляційної системи (CFVS) по очищенню газоповітряної суміші при наплавленні. Пропонована система складається 3 газового забірника, фільтрів, контейнерів для збірки твердих частин, тверда складова зварювального аерозоля (ТСЗА), газоподібною складовою зварювального аерозоля (ГСЗА). і корпуси, спеціальної вентиляційної системи 3 регулюванням швидкості і об'єму витяжки. Проведені дослідження для очищення зварювальних аерозолів (ЗА) при наплавленні високолегованих зносостійких сплавів типу сормайт 3 використанням системи CFVS. Застосовуються спеціальні CFVS, фільтри зокрема механічний, електричний, хімічний (сорбційний). Необхідно не просто уловити ЗА, а відфільтрувати в замкнутій системі, очистити і подати відфільтрований чисті й повітря в зону наплавлення, при цьому не мають порушені технологія і металургійні властивості процесу наплавлення.

Особливості механічного очищення в технологіях наплавлення, характеризується тим що газоповітряна суміш має температуру, яка впливає на сорбент. Механічне очищення в технологіях наплавлення, характеризується тим що газоповітряна суміш має температуру, яка впливає на сорбент. Механічне очищення за допомогою відцентрової камери очищення (ВКО) - це модернізований циклонний фільтр де використовувалися відцентрові сили і сили тяжіння. Відрізняється від існуючих циклічних фільтрів наявністю конічною гвинтовою вставкою і перфорованою поверхнею конуса, який ії охоплює. . У вхідному тангенціальному патрубку утворюється, аеросуміші розділяється на декілька потоків тих, що вводяться в гвинтову вставку.

У електричному фільтрі (електростатичні) на частки і газові молекули діють електричні сили (заснований на явищ іонізації газових молекул, електричним зарядом в електричному полі). Часткам повідомляється електричний заряд, і вони під дією електричного поля осідають 3 газового потоку. Якщо такий газ, що містить деяку кількість носіїв зарядів, помістити між електродами, сполученими 3 джерелом високої напруги, то іони і електрони почнуть рухатися по силовими лініям поля. Це поважно при нейтралізації ГССА.

Ключові слова: шкідливі речовини, зварювальні аерозолі, замкнута фільтровентиляційна система, газоподібній складовій зварювального аерозоля, механічний фільтр, електричний фільтр. 